\title{
NEGOTIATIONS, EXPROPRIATION AND COMPENSATION FOR ESTABLISHING CEMETERIES IN POLAND AN OVERVIEW OF THE SUBJECT MATTER
}

\begin{abstract}
The subject matter of this work is the functioning of a specific market of undeveloped real estate intended for cemeteries. There is a need in Poland not only to expand the existing cemeteries but also to establish new ones. However, such investments are successfully made only in a few gminas, not to mention big cities, where they seem even harder to be carried out. The aim of this article is to outline the issues of negotiations, expropriation and compensation in the process of investment implementation in Poland. In the negotiation process between a gmina (commune) and a private entity, carried out for the purchase of land intended for cemeteries, it has been proved that the gmina must assume the cost of the investment at approximately $55 \%$ of the purchase price of land intended for single-family housing on a given local market. Additionally, the author indicates the limitations associated with the location of investments in local spatial development plans as well as the limitations in terms of conducting effective negotiations for purchasing land intended for cemeteries by means of an agreement. The main problem indicated in the work is the location damage (suffered or not), which has largely contributed to blocking the contractual purchase of land and substantially complicates and delays termination of the expropriation procedure.
\end{abstract}

Keywords: expropriation, compensation, cemeteries, Poland.

\section{Introduction}

Cemeteries are not only places of burial of the deceased, but also places of meditation and reflection on varied cultural aspects as well as natural, architectural and scenic values (NIK 2016: 5). These places are reserved for the burial of the dead, regardless of the legal status, owner/manager or the size of the area, and include elements of greenery (GUS 2015). The indicated fundamental aim of the functioning of a cemetery is associated with the religious function of this place 
in Poland. Apart from this, cemeteries in Europe begin to fulfil the need of local communities, in particular in big cities, to have access to large public spaces serving as places of reflection, contemplation, inspiration, relaxation, places where people can walk to work, to a bus stop or to other public services, and even as places of mutual social and intercultural relations (Cf. Deering 2010; Niţă et al. 2014; Swensen et al. 2016; Woodthorpe 2011).

Research on cemeteries has been conducted mainly by historians (e.g. Skłodowski 2013), geographers (e.g. Klima 2011; Wiercińska 2012; Tobiasz-Lis 2016), sociologists (e.g. Herman 2010), urbanists (e.g. Bennett, Davies 2015; Coutts et al. 2011; Kjøller 2012) and philologists (e.g. Kolbuszewski, Karasek 1996). A few economists have also undertaken this subject matter, focusing on some of its aspects. For instance, B. Faye and F. Channac (2017) as well as P. Canofari et al. (2013) have analysed the prices of burial plots, I. Hussein and J. Rugg (2003), M.E. Wickersham and R. Yehl (2013), T. Longoria (2014), have studied the management of cemeteries, while D. Harrington and J. Treber (2013) have examined the market for funeral services.

In this background, a few basic conclusions may be drawn. First of all, there are hardly any analyses made by economists referring to the subject matter of cemeteries in Poland. Secondly, there occur some serious economic problems in the process of establishing new cemeteries in Poland, especially in terms of prices and market values of purchased or repossessed real estate. It is highlighted that these issues are becoming more and more important for the sustainable development of cemeteries in Poland. Comparing the relation between the area of cemeteries to the area of selected large cities in Poland (Warszawa, Poznań, Szczecin), which amounts to $0.7 \%$, it shall be noticed that these cites resemble the average in French cities, which equals 0.69\% (Faye, Channac 2017: 2840). Nonetheless, when we take a look at some cities which are smaller in terms of their area, this relation drops to $0.4 \%$, as in Kalisz for example. It shall be noticed that not many gminas have established new cemeteries or considerably expanded the territory of the old ones in the $21^{\text {st }}$ century. There is a wide information and statistical gap concerning this matter in Poland, which makes it quite difficult to provide accurate data. Cemeteries are constantly being filled up, with some already not having any more vacant places. On the one hand, what hinders future investments in this respect is the lack of proper areas which would meet legal requirements (Cf. NIK 2016). Furthermore, there are some fundamental problems in the process of purchasing land for cemeteries.

Thus, it seems justified to study the issue of the existing limitation in the process of expropriation and compensation, and consequently the shape of the market of real estate intended for cemeteries. This study is only an outline of the issues and a contribution to further in-depth research in this area. The first part of the study presents the legal and location conditions for establishing cemeteries in Poland. In 
the subsequent part, the author indicates possible price space for negotiations in the purchase of land for the cemetery by a gmina from private entities. Finally, the last part deals with the issue of property compensation.

\section{Location and legal conditions for establishing cemeteries in Poland}

There are two types of cemeteries in Poland: civil cemeteries, which serve the purpose of burying civilians, and military cemeteries, serving as burial places for soldiers. Among civil cemeteries there is a large number of municipal cemeteries, amounting to approximately 1880 , and a much smaller number of denominational cemeteries. The largest number belongs to cemeteries which used to be denominational, and in the 1970s-1990s were handed over to local governments under municipalisation decisions and became municipal cemeteries (NIK 2016: 5). Establishing and expanding municipal cemeteries belongs to the so-called own tasks of gminas, whereas church authorities decide upon the establishment or expansion of denominational cemeteries. The establishment or expansion of cemeteries is decided upon by the Gmina Council or Town/City Council (in towns/cities with poviat rights) in the case of municipal cemeteries, and by church authorities in the case of denominational cemeteries, after obtaining permission from a right sanitary inspector (Article 1 of UCiCHZ). Local governments are obliged to provide proper sanitary and technical conditions to cemeteries as well as to finance their maintenance. The receipts from charges for cemetery services constitute gminas' own income. Maintaining and administering municipal cemeteries belongs to commune heads, town mayors and city mayors. In practice, these tasks are frequently delegated to gmina-owned enterprises and local government budgetary establishments, and less frequently to contractors chosen by means of public procurement. However, delegating most tasks to external entities does not exempt the gmina organs from the obligation to control and supervise (NIK 2016: 5).

A predominant assumption following from the literal interpretation of Article 3 of $\mathrm{UCiCHZ}$ and judicial decisions is that the basis for locating a cemetery shall only be a local spatial development plan (Cf. e.g. District Administrative Court in Bydgoszcz, II SA/Bd 1119/12). In the case of lack of a local spatial development plan, there is an assumption that it is impossible to establish the location for a new cemetery or expand the borders of an existing one by means of a decision to establish the location for a public investment under Article 50, point 1 of UPiZP (Contradictory viewpoint in: Brzezicki, Fisz 2014). The gmina organs responsible for locating a cemetery on a given area should design areas for cemeteries in local development plans in such a way so as to guarantee the fulfilment of the requirements concerning its location, in particular the requirement which says that there shall be no residential buildings within 50 meters of the borders of 
a cemetery (RSan, $\S 3$ ust. 1). Additionally, permission to establish a cemetery may be granted only when the proceedings taken by a sanitary inspector prove that all sanitary conditions have been provided in order to meet the objective of protecting human health (e.g. District Administrative Court in Lublin, III SA/Lu 497/11).

Taking into consideration the necessity to adapt or change the local spatial development plan for the part of a gmina which would make it possible to localise or enlarge a cemetery on a given area, it shall be highlighted that it is a very lengthy and costly process. On the one hand, there occurs a problem of NIMBY objects (Not In My Back Yard), to which cemeteries definitely belong (Zuziak 1995; Dmochowska-Dudek 2011). On the other hand, real estate owners are entitled to compensation due to a change in the local spatial development plan (Article 36, point1and 4, UPiZP). If the access to the real estate or some of its parts in the current manner or according to the current purpose is no longer possible or greatly limited due to an adaptation of a new development plan or a change in the existing plan, the owner of the real estate may demand compensation from a gmina for the actual damage (location damage) suffered or demand buying out the real estate or some of its parts. This claim expires after the period of 10 years (Supreme Court 2016, II CSK 53/16). In the case of a decrease in the real estate value due to an adaptation of a new development plan or a change in the existing one, when the owner sells the real estate and does not exercise the above rights (location damage), they may demand compensation from a gmina equal to the decrease in the real estate value. Such claims may be made within 5 years of the day in which the development plan or its change comes into force.

In the light of the above, gminas have to take into consideration the financial effects of adapting or changing local spatial development plans. What has to be noticed at this point is that social awareness of the location damage at the date in which the damage occurred is still relatively low. This problem is further deepened by the fact that the information about adapting or changing development plans in Poland is not provided directly to real estate owners affected by the change. Moreover, owners do not monitor gminas' activities concerning the adaptation of or change in the plans. Consequently, the owners would like to add compensation for the location damage to the value of the real estate sold to a gmina by means of an agreement, through negotiations for purchasing or repossessing the real estate by the decision about expropriation or a different decision about compensation. This element constitutes one of the greatest limitations for conducting the proceedings connected with purchasing areas intended for cemeteries.

As a result of the above-mentioned aspects, it is difficult to obtain proper areas for locating cemeteries in cities. In the face of these limitations, municipal cemeteries have begun to emerge in smaller gminas, with an aim to fulfil the needs of neighbouring agglomerations which administered them. Thus, there is 
a systemic departure from the provisions of the law, since the maintenance and administration of cemeteries should belong to the heads and mayors of gminas, towns and cities within which the cemeteries are located (Article 2, point 1 of UCiCHZ). According to the Supreme Audit Office (NIK 2016: 11), it is crucial to introduce a regulation which would make it possible to locate a municipal cemetery outside the borders of a gmina, the community of which the cemetery would be intended to serve, with a simultaneous introduction of a regulation specifying the manner of dividing the authority within making local law and administering the necropolis, including the authority of the organs of the gmina on the area on which the cemetery is located as well as the authority of the gmina whose purposes the cemetery will serve.

\section{Prices of areas purchased for cemeteries achievable in negotiations between a private entity and a gmina - initial conclusions from the city of Kalisz}

The first stage of the process of purchasing real estate for a cemetery requires holding negotiations between a gmina and the real estate owner in order to purchase the area by means of an agreement. In the case of cemeteries, we are dealing with an atypical real estate market. Nationally, the turnover of this type of undeveloped real estate intended for cemeteries is very modest (several transactions per year). During negotiations between natural or legal persons and the gmina, it is necessary to estimate the value of the property, which is a reference point. It is not the intention of this text to present the approaches and methods of property valuation. The relationship between the unit prices of land for cemeteries and the prices of land for single-family housing is shown to illustrate the costs of investment implementation by municipalities. Moreover, it is emphasized that only selected aspects of the case study of the city of Kalisz have been used.

In order to illustrate this relation, the author has examined the city of Kalisz located in the south-west part of Poland, on the South Greater Poland Lowland (Nizina Południowowielkopolska), in the Prosna River valley. There are approximately 102 thousand residents registered both permanently and temporarily in Kalisz (at the end of December 2016). The city of Kalisz is one of four cities with poviat rights in the Greater Poland (wielkopolskie) voivodeship. On 1 January 2000, the administrative borders of the city were expanded to encompass the sołectwo of Dobrzec, Sulisławice and Sulisławice Kolonia. The unemployment rate in Kalisz ranked below the average in the Greater Poland voivodeship and much below the average in Poland. The authorities of the city of Kalisz and the business environment in the city have played an active role in obtaining domestic and foreign investors. The city is a seat for companies from such sectors as aviation, food, light industry and automotive industry. The road 
and sewerage infrastructure is systematically extended. The city is also characterised by its academic potential.

The temporal scope of the research encompassed the years 2015-2017. In that time, there were 5 purchase-sale transactions involving undeveloped real estate intended for cemeteries. The real estate was located on the outskirts of Kalisz. A monthly price change was assumed at the level of $0.15 \%$. The transactional prices updated with a time trend ran within the range of $44 \mathrm{zz} / \mathrm{m}^{2}$ to $53 \mathrm{z} / \mathrm{m}^{2}$, with an average price amounting to $47 \mathrm{zz} / \mathrm{m}^{2}$, standard deviation of $4 \mathrm{zz} / \mathrm{m}^{2}$ and a median of $46 \mathrm{zz} / \mathrm{m}^{2}$. The diversity of the sample under analysis is slow, with a coefficient of variation being $8 \%$.

In comparison, in the same period of time there were 225 transactions including the real estate intended for single-family residential housing in the city of Kalisz. A monthly price change was assumed at the level of $0.15 \%$. The transactional prices updated with a time trend ran within the range of $25 \mathrm{z} / / \mathrm{m}^{2}$ to $229 \mathrm{zz} / \mathrm{m}^{2}$, with an average price amounting to $91 \mathrm{z} / \mathrm{m}^{2}$, standard deviation of $38 \mathrm{zz} / \mathrm{m}^{2}$ and a median of $83 \mathrm{zz} / \mathrm{m}^{2}$. The diversity of the sample under analysis is high, with a coefficient of variation amounting to $42 \%$.

The relation between the medians of the two groups of undeveloped real estate intended for different purposes, i.e. for cemeteries and for single-family residential housing, is $46 \mathrm{z} / / \mathrm{m}^{2}$ to $83 \mathrm{zz} / \mathrm{m}^{2}$. Thus, the updated transactional prices of the real estate intended for cemeteries run at the level of approximately $55 \%$ of the transactional prices of the real estate intended for single-family residential housing. Such a difference, in the case of changing the intended use of the real estate from single-family residential housing areas to cemetery areas in a local spatial development plan, indicates a location damage suffered by the owner when the plan is changed. It is obvious that the estimated bases for determining the compensation due to the location damage may differ from the presented comparison of the median of updated transactional prices. Nonetheless, this comparison fully reflects the essence of the problem. The negotiations between a gmina and a real estate owner for purchasing the real estate by means of an agreement frequently encompass the issue of the location damage (actual or not), which is not included in the scope of the negotiations.

\section{Compensation rules for areas repossessed for cemeteries}

In the case of a failure at the stage of negotiations, a procedure of direct expropriation is launched with the aim of transferring the real estate ownership rights. The expropriation of real estate may be executed if public goals cannot be realised in a way other than by depriving or limiting someone's rights to the real estate, and these rights cannot be purchased by means of an agreement. A district governor, who executes tasks within the scope of government administration, is 
the right organ with regard to the expropriation matters. In this case, the public goal is establishing and maintaining cemeteries (Article 6, point 9 of UoGN). Expropriation of the ownership rights to real estate shall be executed in return for compensation to the expropriated person equivalent to the values of lost rights. The basis for determining the compensation is the market value of the real estate specified by a real estate appraiser.

In an appraisal report on the real estate intended for cemeteries and expropriated by means of an administrative decision, a compulsory and fundamental task of an appraiser is to refer to the principle of advantage included in Article 134 of UoGN. While determining the market value of real estate, the appraiser should take into consideration primarily its type, location, manner of use, intended use, condition of the real estate and the current shape of prices in real estate trade. The value of the real estate for compensation purposes is specified according to the current manner in which it is used, if the intended use of the real estate, consistent with the purpose of expropriation, does not cause a growth in its value. If the intended use of the real estate, consistent with the purpose of expropriation, results in the growth in its value, the real estate value for compensation purposes shall be determined according to an alternative manner of its use, resulting from this intended use. There are two possible groups of solutions while determining the value of the real estate intended for cemeteries, making up two basic scenarios, i.e.:

1. No, without an advantage: Current manner of use $>$ Alternative manner of use; 2. Yes, with an advantage: Current manner of use $<$ Alternative manner of use.

In the case where the current manner of real estate use differs from its intended use following the purpose of expropriation, different market analyses should be made for the condition corresponding with the current manner of use of the real estate and the condition matching the intended use in accordance with the purpose of expropriation. If the results of the analyses of real estate transactional prices corresponding with the current manner of use and intended purpose of the real estate following the purpose of expropriation indicate prices at a similar level, separate valuations should be conducted and a higher value of the real estate should be taken as the basis for the valuation of compensation. However, if the results of the analyses of real estate transactional prices corresponding with the current manner of use and intended purpose of the real estate following the purpose of expropriation indicate prices at different levels, the valuation should be conducted on the basis of the analysis indicating a higher level of prices.

UoGN indicates correctly that if the intended use of the real estate - public goal as the purpose of expropriation - causes its value to grow, then the market value shall be determined according to the manner of use resulting from this intended use (Bieniek et al. 2012: 798). In this case, the directions specified in the Judgement of the Supreme Administrative Court of 8 April 2016, sygn. I 
OSK 1686/14, seem to be of particular importance: "If the value of the real estate determined according to its intended use for the purpose of expropriation is higher than the value specified according to its current manner of use, the legislator shall grant the expropriated persons the advantage right in the form of establishing compensation on the basis of the intended use of the real estate - according to the criteria which increase the real estate value. The expropriated persons are entitled to compensation adequate to the existing possibilities of developing the real estate, since the value of the real estate is determined not only by its current manner of use, but also by the entire range of possibilities of using it within the existing law".

Let's look at some examples for each of the scenarios. In the first group of solutions, there is a no advantage rule. There may occur a scenario in which real estate is intended for single-family residential housing, and one of its parts becomes expropriated in order to realise an investment related with establishing a cemetery. In such a case, the market value of the real estate intended for residential housing and the market value of the real estate intended for a cemetery should be appraised, and a higher value should be chosen: most frequently MVRH $>$ MVCM, thus the current manner of use $>$ the alternative manner of use. In the second group of solutions, there occurs an advantage rule. There may be a scenario in which the real estate is intended for agriculture and one of its parts is expropriated for an investment related with establishing a cemetery. In such a case the market value of the real estate intended for agriculture and the market value of the real estate intended for a cemetery should be appraised, and a higher value should be chosen: most frequently MVA $<$ MVCM, thus the current manner of use $<$ the alternative manner of use.

\section{Conclusions}

The issue of expanding and establishing cemeteries in Poland is growing, despite a partial change in the forms of burying the deceased. Gminas are obliged to provide public services to all the inhabitants, yet the accessibility of these services might be more and more frequently limited due to the lack of burying places on municipal cemeteries on the area of a given gmina (NIK 2016: 13). On the other hand, gminas do not undertake actions in order to eliminate the accessibility barrier for burying places by expanding existing cemeteries or establishing new ones, as well as by making inter-gmina agreements which would enable the functioning of a common municipal cemetery for more than just one gmina. The author of this work has also indicated planning limitations for localising new cemeteries, especially in big cities, as well as the problem of purchasing land for cemeteries. Dividing the process of setting up or expanding cemeteries into two crucial stages: localisation and purchasing of land (negotiations or expropriation, in case of a failure in negotiations), does not seem to 
be an effective solution. This may result from the existence of location damage and the fact that its regulation takes place in the proceedings which are separate from land purchase. Furthermore, there occur situations in which real estate owners formulate expectations concerning the purchase price of land including the value of the location damage which they have not suffered. The expectations concerning the sale price offer are based on potential possibilities (not realised before) of using the real estate before a change in the local spatial development plan. In the negotiation process between a gmina and a private entity, carried out for the purchase of land intended for cemeteries, it has been proved that the gmina must assume the cost of the investment at approximately 55\% of the purchase price of land intended for single-family housing on a given local market.

\section{References}

Bennett G., Davies PJ., 2015, Urban cemetery planning and the conflicting role of local and regional interests, "Land Use Policy", 42: 450-459.

Bieniek G., Gdesz M., Matusik G. Mzyk E., Kalus S., 2012, Ustawa o gospodarce nieruchomościami. Komentarz, LexisNexis Polska Sp. z o.o., Warszawa.

Brzezicki T., Fisz I., 2014, Lokalizacja Cmentarza, "Nieruchomości", 4: 12-15.

Canofari P., Marini G., Scaramozzino P., 2013, To sleep, perchance to dream: Prices for funeral homes in US states, Research Paper Series, 11/2(260), CEIS, University of Rome.

Coutts C., Basmajian C., Chapin T., 2011, Projecting landscapes of death, "Landscape and Urban Planning", 102(4): 254-261.

Deering B., 2010, From anti-social behaviour to X-rated: Exploring social diversity and conflict in the cemetery, [in:] Madrell A., Sidaway J.D. (eds.), Deathscapes: Spaces for Death, Dying, Mourning and Remembrance: 75-94, Ashgate, Farnham.

Dmochowska-Dudek K., 2011, Obiekty NIMBY jako przyktad konfliktowych inwestycji na terenach mieszkaniowych - teoretyczny zarys problemu, "Space-Society-Economy", 10: 29-56.

Faye B., Channac F., 2017, A hedonic approach to burial plot value in French cemeteries, "Urban Studies", 54(12): 2835-2855.

GUS - Główny Urząd Statystyczny, 2015, Życie religijne w Polsce, Warszawa.

Harrington D., Treber J., 2013, Cemeteries and mortuaries: Better together or apart?, Regulation (Winter 2012-2013): 40-47.

Herman A., 2010, Death has a touch of class: Society and space in Brookwood Cemetery, 1853-1903, "Journal of Historical Geography", 36(3): 305-314.

Hussein I., Rugg J., 2003, Managing London's dead: A case of strategic policy failure, "Mortality", 8(2): 209-221.

Kjøller CP., 2012, Managing green spaces of the deceased: Characteristics and dynamics of Danish cemetery administrations, "Urban Forestry \& Urban Greening", 11(3): 339-348.

Klima E., 2011, Przestrzeń religijna miasta Łódź, Wydawnictwo Uniwersytetu Łódzkiego, Łódź: 1-426. 
Kolbuszewski J., Karasek K., 1996, Cmentarze, Wydawnictwo Dolnośląskie, Wrocław.

Longoria T., 2014, Are we all equal at death? Death competence in municipal cemetery management, "Death Studies", 38(6): 355-364.

NIK - Najwyższa Izba Kontroli, 2016, Zarządzanie Cmentarzami Komunalnymi. Informacja o wynikach kontroli, LPO.430.002.2016 Nr ewid. 155/2016/P/16/087/LPO, Delegatura w Poznaniu, Warszawa.

Niţă M.R., Iojă I.C., Rozylowicz L., Onose D.A., Tudor A.C., 2014, Land use consequences of the evolution of cemeteries in the Bucharest Metropolitan Area, "Journal of Environmental Planning and Management", 57: 1066-1082.

RSan - Rozporzadzenie Ministra Gospodarki Komunalnej z dnia 25 sierpnia 1959 roku w sprawie określenia, jakie tereny pod względem sanitarnym sa odpowiednie na cmentarze, Dz.U., 1959, nr 52, poz. 315.

Skłodowski J.T., 2013, Cmentarze na Żmudzi. Polskie ślady przeszłości Obojga Narodów, Ministerstwo Kultury i Dziedzictwa Narodowego, Warszawa.

SN, 2016, Wyrok Sądu Najwyższego z 20 października 2016 roku, II CSK 53/16.

Swensen G., Nordh H., Brendalsmo J., 2016, A green space between life and death - a case study of activities in Gamlebyen Cemetery in Oslo, Norway, "Norsk Geografisk Tidsskrift - Norwegian Journal of Geography", 70(1): 41-53.

Tobiasz-Lis P., 2016, Czas w przestrzeni miasta. Przykład Łodzi, Wydawnictwo Uniwersytetu Łódzkiego, Łódź.

UCiCHZ - Ustawa z dnia 31 stycznia 1959 roku o cmentarzach $i$ chowaniu zmarlych, tekst jednolity, Dz.U., 2017, poz. 912.

UPiZP - Ustawa z dnia 27 marca 2003 roku o planowaniu i zagospodarowaniu przestrzennym, tekst jednolity, Dz.U., 2017, poz. 1073, ze zm.

Wickersham ME., Yehl R., 2013, Public cemetery: Meeting new challenges in a time of change, "Public Manager", 42(4): 62-65.

Wiercińska A., 2012, Cmentarze łódzkie na tle rozwoju ludnościowego i przestrzennego miasta, "Studia z Geografii Politycznej i Historycznej”, 1: 207-220.

Woodthorpe K., 2011, Sustaining the contemporary cemetery: Implementing policy alongside conflicting perspectives and purpose, "Mortality", 16: 259-276.

WSA w Bydgoszczy, 2013, Wyrok Wojewódzkiego Sąu Administracyjnego siedziba w Bydgoszczy z dnia 3 kwietnia 2013 roku, II SA/Bd 1119/12.

WSA w Lublinie, 2012, Wyrok Wojewódzkiego Sądu Administracyjnego siedziba w Lublinie z dnia 7 lutego 2012 roku, III SA/Lu 497/11.

Zuziak Z.K., 1995, Rozwiązywanie konfliktów środowiskowych w gospodarce przestrzennej, [in:] Salomon et al. (eds.), Gospodarka samorzadów terytorialnych $w$ świetle doświadczeń amerykańskich, Fundacja Promocji Czystych Technologii TECHEKO, Łódź, AB. 


\section{NEGOCJACJE, WYWLASZCZENIE I ODSZKODOWANIE W PROCESIE ZAKLADANIA CMENTARZY W POLSCE ZARYS PROBLEMATYKI}

Zarys treści: $\mathrm{W}$ opracowaniu podjęto problematykę funkcjonowania nietypowego rynku nieruchomości niezabudowanych przeznaczonych pod cmentarze. W Polsce występuje potrzeba powiększania i zakładania nowych cmentarzy. Nieliczne gminy potrafią skutecznie przeprowadzić takie inwestycje. Największe trudności występują w miastach. Celem niniejszego artykułu było zarysowanie problematyki negocjacji, wywłaszczeń i odszkodowań w procesie realizacji inwestycji w Polsce. W procesie negocjacji pomiędzy gminą a podmiotem prywatnym realizowanym dla nabycia gruntów przeznaczonych pod cmentarze dowiedziono, że gmina musi zakładać koszt realizacji inwestycji na około 55\% ceny zakupu gruntów, przeznaczonych pod zabudowę mieszkaniową jednorodzinną na danym rynku lokalnym. W opracowaniu wskazano na ograniczenia związane z lokalizacją inwestycji w miejscowych planach zagospodarowania przestrzennego oraz ograniczenia w zakresie efektywnego przeprowadzenia rokowań o nabycie gruntów przeznaczonych pod cmentarz w drodze umowy. Wskazano, że głównym problemem jest szkoda lokalizacyjna (zaistniała lub nie), która w znacznym stopniu przyczynia się do zablokowania trybu umownego wykupu gruntu i zasadniczo komplikuje i przeciąga w czasie zakończenie procedury wywłaszczeniowej.

Słowa kluczowe: wywłaszczenie, odszkodowanie, cmentarze, Polska.

Dr hab. Piotr Lis, prof. UEP

Poznan University of Economics and Business Department of Business Activity and Economic Policy e-mail: piotr.lis@ue.poznan.pl 